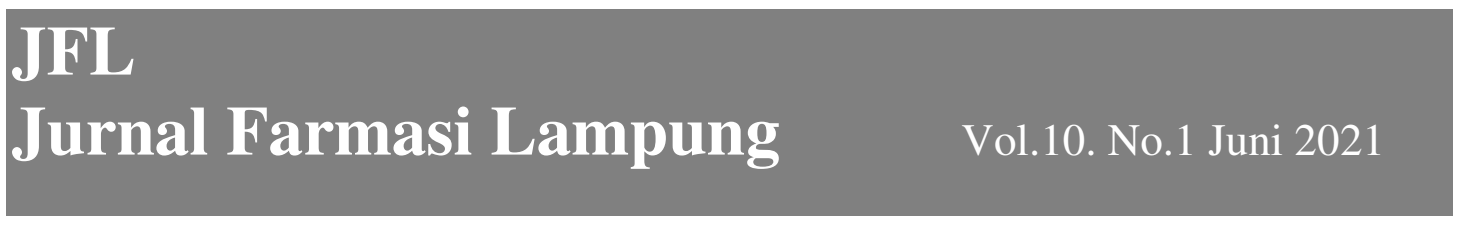

\title{
UJI AKTIVITAS ANTIBAKTERI EKSTRAK ETANOL BAWANG DAYAK (Eleutherine polmifolia (L.) Merr) TERHADAP Salmonella typhi DAN Escherichia coli
}

\author{
Nofita $^{1)}$, Selvi Marcellia ${ }^{2)}$, Ade Untari ${ }^{2)}$ \\ Program Studi Farmasi, Universitas Malahayati Bandar Lampung, Indonesia
}

\begin{abstract}
Dayak onion (Eleutherine polmifolia (L.) Merr) was a typical plant of Kalimantan. Empirically dayak onion (Eleutherine polmifolia (L.) Merr) used by the comunity to treat skin infections. The purpose of this study was to determine the antibacterial activity of ethanol extract of dayak onion power against Salmonella typhi and Escherichia coli bacteria. The highest concentration used was $100 \%$, and the lowest concentration was $0,5 \%$. As a control of cloramfenikol for Salmonella typhi and ciprofloxacin for Escherichia coli bacteria. This research method used agar diffusion. The results showed the ethanol extract of dayak onion (Eleutherine polmifolia (L.) Merr) contained flavonoids, alkaloids, tannins and phenols with the highest levels was by tannins at 7,45\%. Dayak onion (Eleutherine polmifolia (L.) Merr) are inhibiting the growth of Salmonella typhi bacteria at a minimum inhibitory concentration (MIC) of $1 \%$ with a inhibition zone diameter of $6,24 \mathrm{~mm}$ and $0,9 \%$ with a inhibition zone diameter of $6,20 \mathrm{~mm}$ at Escherichia coli bacteria.
\end{abstract}

Keywords : Eleutherine polmifolia (L.) Merr, Salmonella typhi, Escherichia coli, Agar diffusion, MIC

\begin{abstract}
ABSTRAK
Bawang dayak (Eleutherine polmifolia (L.) Merr) merupakan tanaman khas Kalimantan. Secara empiris bawang dayak (Eleutherine polmifolia (L.) Merr) sudah digunakan masyarakat untuk mengobati infeksi kulit. Tujuan penelitian ini adalah untuk mengetahui aktivitas antibakteri ekstrak etanol bawang dayak (Eleutherine polmifolia (L.) Merr) terhadap bakteri Salmonella typhi dan Eschericia coli. Konsentrasi tertinggi yang digunakan adalah $100 \%$, dan konsentrasi terendah yaitu $0,5 \%$. Sebagai kontrol positif kloramfenikol untuk bakteri Salmonella typhi dan ciprofloxacin untuk bakteri Escherichia coli. Metode penelitian ini menggunakan difusi agar. Hasil penelitian menunjukan bahwa ekstrak etanol bawang dayak (Eleutherine polmifolia (L.) Merr) mengandung flavonoid, alkaloid, tanin dan fenol dengan kadar tertinggi yaitu tanin sebesar $7,45 \%$. Bawang dayak (Eleutherine polmifolia (L.) Merr) bersifat menghambat pertumbuhan bakteri Salmonella typhi pada konsentrasi hambat minimum (KHM) 1\% dengan diameter zona hambat sebesar 6,24 mm dan konsentrasi 0,9\% dengan diameter zona hambat sebesar 6,20 $\mathrm{mm}$ pada bakteri Escherichia coli.
\end{abstract}

Kata kunci : Eleutherine polmifolia (L.) Merr, Salmonella typhi, Escherichia coli, , Difusi agar, KHM 


\section{PENDAHULUAN}

Infeksi saluran pencernaan merupakan masalah kesehatan di negara berkembang. Infeksi merupakan penyakit yang paling banyak di temukan dalam kehidupan sehari-hari. Kasus infeksi biasanya disebabkan oleh beberapa mikroorganisme seperti bakteri, virus, jamur, dan parasit. Bakteri yang sering menimbulkan infeksi pada saluran pencernaan manusia adalah Salmonella typhi, Escherichia coli, Shigella, Vibrio, dan Clostridia perfingens (Scallan, 2012).

Salmonella typhi dan Escherichia coli adalah flora normal yang merupakan strain bakteri yang menyebabkan terjadinya demam tifoid dan diare. Salmonella typhi dan Escherichia coli masuk ke dalam tubuh melalui makanan atau minuman yang tercemar dan dapat menyebabkan penyakit tifus dan diare.

WHO (2018) memperkirakan jumlah kasus demam tifoid di seluruh dunia mencapai 21 juta jiwa kasus dengan 128.000 sampai 161.000 kematian setiap tahun. Indonesia penderita demam tifoid mencapai angka 81\% per 100.000 (Depkes RI, 2013).

Penyakit diare merupakan penyebab kematian utama di dunia, terhitung 510 juta kematian pertahun (Basailin et al., 2018). Prevalensi diare di Indonesia tahun 2017 yaitu 4.274.790 penderita atau $60,4 \%$ ( Kemenkes RI, 2017).

Demam tifoid dan diare dapat diobati dan dicegah dengan terapi farmakologi maupun non farmakologi. Penggunaan obat sintesis bisa menimbulkan efek samping yang tidak diinginkan. Hal ini meningkatkan kesadaran masyarakat untuk kembali ke alam ( back to nature) dengan memanfaatkan obat-obat alami (Djauhariya dan Hernani, 2004). Obat tradisional semakin banyak dipilih karena lebih aman daripada obat sintesis, harga obat lebih murah dan efek samping yang kecil.

Bawang dayak (Eleutherine palmifolia (L.) Merr) merupakan salah satu tumbuhan khas Kalimantan yang berkhasiat sebagai obat tradisional. Masyarakat suku Dayak percaya bahwa mengkonsumsi bawang dayak (Eleutherine palmifolia (L.) Merr) dapat mengobati penyakit infeksi kulit apabila sistem tubuh rendah (Puspadewi, 2013).

Umbi bawang dayak (Eleutherine palmifolia (L.) Merr) mengandung senyawa metabolit sekunder yaitu flavonoid, alkoloid, tanin, glikosida, fenolik, steroid, kuinon, dan minyak atsiri. Senyawa metabolit merupakan sumber obat sehingga berpotensi untuk di kembangkan sebagai tanaman obat modern dalam kehidupan manusia (Febrinda, 2013).

Penelitian yang telah ada menunjukkan bawang dayak (Eleutherine palmifolia (L.) Merr) memiliki aktivitas antibakteri terhadap Staphylococcus aureus (Warsiti, 2018) dan Staphylococcus epidemidis (Novaryatiin et al., 2018) dalam beberapa konsentrasi yaitu $1 \%, 5 \%$, $10 \%$, dan $15 \%$. Semakin tinggi konsentrasi bawang dayak (Eleutherine palmifolia (L.) Merr) yang digunakan akan semakin baik daya hambatnya. 
Belum ditemukannya penelitian aktivitas antibakteri bawang dayak terhadap bakteri penyebab infeksi saluran pencernaan. Berdasarkan hal tersebut peneliti tertarik untuk mengetahui kemampuan daya hambat ekstrak etanol bawang dayak (Eleutherine palmifolia (L.) Merr) terhadap bakteri Salmonella typhi dan Escherichia coli dan berapa konsentrasi hambat minimum ekstrak etanol bawang dayak (Eleutherine palmifolia (L.) Merr) untuk menghambat Salmonella typhi dan Escherichia coli.

\section{METODE PENELITIAN Alat dan Bahan}

Alat yang digunakan pada penelitian ini yaitu oven, lemari pendingin, Hotplate, Autoclave, jarum ose, pinset, lidi kapas steril, cawan petri, Erlenmeyer, Beaker glass, pipet ukur, bulp, kertas kopi, api spiritus, inkubator, tabung reaksi dan rak tabung, Paper disc, jangka sorong, batang pengaduk (spatula), neraca analitik, pisau, bejana, seperangkat alat perkolasi, kapas, plastik, kertas saring, spektrofotometri.

Bahan yang digunakan dalam penelitian ini yaitu bawang dayak, disk Kloramfenikol, disk Ciprofloxasin, media Salmonella Shigella Agar (SSA), media Triptyc Soy Agar (TSA), media Natrium Agar (NA), aquades, kertas cakram, biakan bakteri Salmonella typhi dan Escherichia coli koleksi Laboratorium Teknik Hasil Pertanian Politeknik Negeri Lampung, standar Mac Farland $\left(\mathrm{BaCl}_{2} 1 \%\right.$ : $\mathrm{H}_{2} \mathrm{SO}_{4} 1 \%$ ), etanol $96 \%$.

\section{Prosedur Penelitian Pembuatan Ekstrak}

Ekstrak bawang dayak dibuat dengan cara perkolasi. 500 gram serbuk simplisia bawang dayak dimasukkan ke dalam wadah, kemudian direndam dengan larutan etanol $96 \%$ selama 3 jam. Pindahkan serbuk simplisia yang telah dimaserasi ke dalam perkolator. Proses ekstraksi dilakukan selama 2 hari, higga cairan menetes dari alat perkolator berwarna bening. Ekstrak cair selanjutnya di evaporasi untuk mendapatkan ekstrak kental.

\section{Skrining Fitokimia}

Uji flavonoid dilakukan dengan larutan sampel $5 \mathrm{ml}$ ditambahkan serbuk magnesium $2 \mathrm{mg}$ dan 3 tetes $\mathrm{HCL}$ pekat, kocok dan diamati perubahan yang terjadi. Hasil positif jika terbentuk warna merah, kuning atau jingga pada sampel.

Uji alkaloid dilakukan dengan larutan sampel $2 \mathrm{ml}$ diuapkan di atas cawan porselin hingga diperoleh isolat. Ekstrak isolat bawang dayak dimasukkan ke dalam tabung reaksi. Pada sampel tersebut ditambahkan 2 tetes pereaksi Dragendroff. Hasil positif apabila dengan pereaksi Dragendroff terbentuk larutan keruh dengan adanya endapan.

Pemeriksaan tanin dilakukan dengan mengambil $5 \mathrm{ml}$ ditambahkan larutan $\mathrm{FeCl}_{3} 10 \%$. Hasil positif jika terjadi perubahan warna menjadi hijau, biru atau hitam.

Pemeriksaan polifenol dilakukan dengan mengambil $2 \mathrm{ml}$ sampel dilarutkan dalam aquades $10 \mathrm{ml}$, dipanaskan 5 menit dan disaring. 
Filtrat yang terbentuk ditambahkan 4-5 tetes $\mathrm{FeCl}_{3} \quad 5 \%$. Hasil positif terbentuknya warna biru tua atau hijau kehitaman (Hanani, 2015).

\section{Penetapan Kadar}

Penetapan kadar flavonoid dilakukan dengan menimbang 100 mg ekstrak, dilarutkan dalam $10 \mathrm{ml}$ etanol. Larutan diambil $2 \mathrm{ml}$ ditambahkan $3 \mathrm{ml}$ etanol, $0,2 \mathrm{ml}$ aluminium klorida $10 \%$, dan 0,2 $\mathrm{ml}$ kalium asetat dicukupkan dengan aquades sampai $10 \mathrm{ml}$. Sampel diinkubasi selama 30 menit pada tempat gelap dengan suhu kamar dan absorbansi diukur pada panjang gelombang $431 \mathrm{~nm}$ (Akstar et al., 2015).

Penetapan kadar alkaloid dilakukan dengan menimbang $25 \mathrm{mg}$ ekstrak dilarutkan dalam $25 \mathrm{ml}$ aquades. Selanjutnya dipipet $1 \mathrm{ml}$ larutan ke dalam labu ukur $10 \mathrm{ml}$ aquades dan disaring. Kemudian ukur absorbansinya pada panjang gelombang $273 \mathrm{~nm}$. Larutan sampel dibuat tiga kali ulangan sehingga didapat kadar rata-rata alkaloid (Aini, 2016).

Penetapan kadar tanin dilakukan dengan menimbang $50 \mathrm{mg}$ dilarutkan dengan etanol sebanyak $50 \mathrm{ml}$. Setelah itu dilakukan pengenceran dengan cara dipipet larutan induk sebanyak $1 \mathrm{ml}$ dilarutkan dengan etanol dalam labu ukur $10 \mathrm{ml}$. Kemudian ukur absorbansinya dengan menggunakan spektrofotometri Uv-Vis dengan panjang gelombang $215 \mathrm{~nm}$. Larutan sampel dibuat tiga kali ulangan sehingga didapat kadar ratarata tanin (Anzharmi et al., 2016).

\section{Peremajaan Bakteri}

Bakteri Salmonella typhi dan Eschericia coli dari biakan murninya diambil sebanyak 1 ose kemudian diinokulasikan dengan cara digores pada Triptyc Soy Agar (TSA) miring, kemudian diinkubasi selama 24 jam.

\section{Pembuatan Suspensi Bakteri}

Bakteri Salmonella typhi dan Escherichia coli diambil sebanyak 1-2 ose dan disuspensikan kedalam larutan $\mathrm{NaCl} \quad 0,9 \quad \%$ sampai diperoleh kekeruhan yang sesuai dengan standar Mc Farland 5 (Misna dan Diana, 2016).

\section{Pembuatan Media Salmonella Shigella Agar (SSA)}

Timbang 6,3 gram media dan larutan ke dalam $100 \mathrm{ml}$ aquades. Larutan diaduk hingga homogen lalu panaskan sampai mendidih agar tercampur sempurna selama 1 menit. Media ditunggu agak dingin sekitar $45^{\circ} \mathrm{C}$ lalu tuang ke cawan petri (Safitri dan Sinta, 2010).

\section{Pembuatan Media Nutrient agar (NA)}

Timbang 2,8 gram Nutrient agar, kemudian larutkan dalam $100 \mathrm{ml}$ aquadest dan panaskan hingga mendidih. Sterilkan selama 15 menit di autoclave dengan tekanan udara 1 atm suhu $121^{\circ} \mathrm{C}$. Setelah di autoclave, agar langsung dituangkan ke dalam cawan petri dan didinginkan hingga agar beku (Misna dan Diana, 2016). 


\section{Uji Aktivitas Antibakteri}

Uji aktivitas antibakteri dilakukan dengan metode difusi cakram, menggunakan paper disc berdiameter $6 \mathrm{~mm}$. Media SSA dan NA yang telah dipanaskan dimasukkan kedalam cawan petri lalu didiamkan hingga memadat. Setelah media memadat suspensi bakteri digoreskan mengunakan kapas steril pada permukaan media yang mengandung berbagai konsentrasi yaitu $100 \%, 80 \%$, $60 \%$, 40\% dan 20\%. Masukkan Paper disc berdiameter $6 \mathrm{~mm}$ yang telah ditetesi larutan kombinasi ekstrak disc antibiotik kloramfenikol sebagai kontrol positif bakteri Salmonella typhi, ciprofloxacin sebagai kontrol positif bakteri Escherichia coli dan disc blank yang ditetesi aquadest sebagai kontrol negatif pada media. Media yang telah diisi diinkubasi pada suhu $37^{\circ} \mathrm{C}$, selanjutnya dilakukan pengamatan dan pengukuran zona hambat yang terbentuk pada 24 jam berikutnya. Amati zona bening yang terbentuk dan ukur diameter daerah hambatnya menggunakan jangka sorong. Perlakuan ini dilakukan sebanyak 3 kali pengulangan. Selanjutnya pengujian KHM.

\section{ANALISIS DATA}

Data hasil pengujian daya hambat ekstrak bawang dayak terhdap bakteri Salmonella typhi dan Escherichia coli dianalisa menggunakan uji statistic Analisis Of Varian (ANOVA) satu arah dengan taraf kepercayaan $95 \%$ untuk mengetahui ada tidaknya pengaruh perbedaan secara signifikan dari data kelompok konsentrasi ekstrak. Kemudian dilanjutkan dengan PostHoc Least Significant Difference (LSD).

\section{HASIL DAN PEMBAHASAN}

Hasil ekstraksi secara perkolasi dengan pelarut etanol $96 \%$ didapatkan hasil rendemen sebanyak $16,56 \%$.

Dari hasil skrining fitokimia menunjukkan hasil bahwa ekstrak bawang dayak (Eleutherine polmifolia (L.) Merr) positif mengandung flavonoid, alkaloid, tanin dan polifenol.

Hasil penetapan kadar ekstrak bawang dayak (Eleutherine polmifolia (L.) Merr) yang dilakukan dengan menggunakan alat spektrofotometri Uv-Vis. Metabolit sekunder yang di uji yaitu flavonoid, alkaloid dan tanin. Hasil yang didapat dari penetapan kadar flavonoid yang didapat lebih rendah yaitu $0,19 \%$ dibandingkan dengan alkaloid yaitu 4,44\% dan tanin sebesar $7,45 \%$, hal ini dimungkinkan karena sifat metabolit sekunder flavonoid memiliki titik didih yang cukup rendah yaitu $64,5^{\circ} \mathrm{C}$ yang memungkinkan senyawa flavonoid mudah menguap (Browning, 1966). Hasil penetapan kadar tanin dan alkaloid cukup tinggi, hal ini sangat berpengaruh dalam menghambat pertumbuhan bakteri.

Hasil uji daya hambat menunjukan bahwa seluruh konsentrasi uji yang digunakan $100 \%, 80 \%, 60 \%, 40 \%$, $20 \%, 18 \%, 15 \%, 12 \%, 9 \%, 6 \%, 3 \%$, $1 \%$ dan $0,9 \%$ memiliki aktivitas antibakteri terhadap Salmonella typhi dan Echerichia coli. Pengujian antibakteri konsentrasi hambat minimum (KHM) bakteri Salmonella typhi dan Escherichia coli diperoleh pada konsentrasi $1 \%$ dan $0,9 \%$ dengan diameter zona hambat sebesar $6,22 \mathrm{~mm}$ dan $6,20 \mathrm{~mm}$ yang menunjukkan bahwa hasil aktivitas 
antibakteri dalam kategori sedang, artinya dalam konsentrasi terendah ekstrak bawang dayak (Eleutherine polmifolia (L.) Merr) masih menunjukkan aktivitas yang cukup besar.

Pada penelitian ini digunakan antibiotik kloramfenikol untuk bakteri Salmonella typhi dan antibiotik ciprofloxacin untuk bakteri Escherichia coli dengan dosis $5 \mu \mathrm{g}$ sebagai kontrol positif, dan aquades steril sebagai kontrol negatif. Kontrol positif pada bakteri Salmonella typhi mampu menghambat dengan diameter zona hambat sebesar 25,34 $\mathrm{mm}$ dan kontrol positif pada bakteri Escherichia coli dengan diameter zona hambat sebesar 26,25 mm. Penggunaan antibiotik kloramfenikol dipilih untuk bakteri Salmonella typhi karena kloramfenikol mempunyai mekanisme menghambat sintesis protein sel mikro dan kloramfenikol merupakan pilihan utama pengobatan demam tifoid karena efektif (Sandika dan Suswandi, 2017). Antibiotik ciprofloxacin dipilih untuk bakteri Escherichia coli karena mempunyai mekanisme dengan menghambat proses replika DNA (Ersita dan Kardewi, 2016).

Hasil penelitian menunjukkan ekstrak bawang dayak (Eleutherine polmifolia (L.) Merr) efektif menghambat Salmonella typhi dan Escherichia coli. Namun, dilihat dari hasil konsentrasi hambat minimum (KHM) ekstrak bawang dayak (Eleutherine polmifolia (L.) Merr) lebih efektif terhadap bakteri Escherichia coli dibandingkan dengan bakteri Salmonella typhi.

Tabel 1. Hasil Pengamatan Diameter Zona Hambat Ekstrak Bawang Dayak Terhadap Bakteri Salmonella typhi dan Escherichia coli

\begin{tabular}{|c|c|c|c|c|c|c|}
\hline \multirow[t]{2}{*}{$\begin{array}{c}\text { Jenis } \\
\text { Bakteri }\end{array}$} & \multirow[t]{2}{*}{ Konsentrasi } & \multicolumn{3}{|c|}{$\begin{array}{c}\text { Diameter Rata-rata Zona } \\
\text { Hambat }(\mathrm{mm}) \\
\text { Pengulangan }\end{array}$} & \multirow{2}{*}{$\begin{array}{c}\text { Rerata } \\
\text { Zona } \\
\text { Hambat } \pm \\
\text { SD (mm) }\end{array}$} & \multirow[t]{2}{*}{$P$} \\
\hline & & I & II & III & & \\
\hline & $100 \%$ & 15,91 & 15,90 & 15,92 & $15,91 \pm, 01$ & \\
\hline & $80 \%$ & 13,82 & 13,83 & 13,84 & $13,83 \pm, 01$ & \\
\hline & $60 \%$ & 11,82 & 11,80 & 11,81 & $11,80 \pm, 01$ & \\
\hline & $40 \%$ & 9,89 & 9,88 & 9,90 & $9,89 \pm, 01$ & \\
\hline & $20 \%$ & 6,93 & 6,94 & 6,92 & $6,93 \pm, 01$ & \\
\hline & $18 \%$ & 6,84 & 6,85 & 6,83 & $6,84 \pm, 01$ & \\
\hline & $15 \%$ & 6,76 & 6,77 & 6,78 & $6,77 \pm, 01$ & \\
\hline & $12 \%$ & 6,67 & 6,66 & 6,68 & $6,67 \pm, 01$ & \\
\hline Salmonella & $9 \%$ & 6,60 & 6,61 & 6,58 & $6,59 \pm, 01$ & 0,000 \\
\hline typhi & $6 \%$ & 6,51 & 6,50 & 6,49 & $6,50 \pm, 01$ & \\
\hline & $3 \%$ & 6,44 & 6,42 & 6,43 & $6,43 \pm, 01$ & \\
\hline & $1 \%$ & 6,21 & 6,23 & 6,22 & $6,22 \pm, 01$ & \\
\hline & $0,9 \%$ & 0 & 0 & 0 &, $00 \pm, 00$ & \\
\hline & $0,8 \%$ & 0 & 0 & 0 &, $00 \pm, 00$ & \\
\hline & $0,7 \%$ & 0 & 0 & 0 &, $00 \pm, 00$ & \\
\hline & $0,6 \%$ & 0 & 0 & 0 &, $00 \pm, 00$ & \\
\hline & $0,5 \%$ & 0 & 0 & 0 &, $00 \pm, 00$ & \\
\hline & Kontrol & 25,33 & 25,35 & 25,34 & $25,34 \pm, 00$ & \\
\hline
\end{tabular}




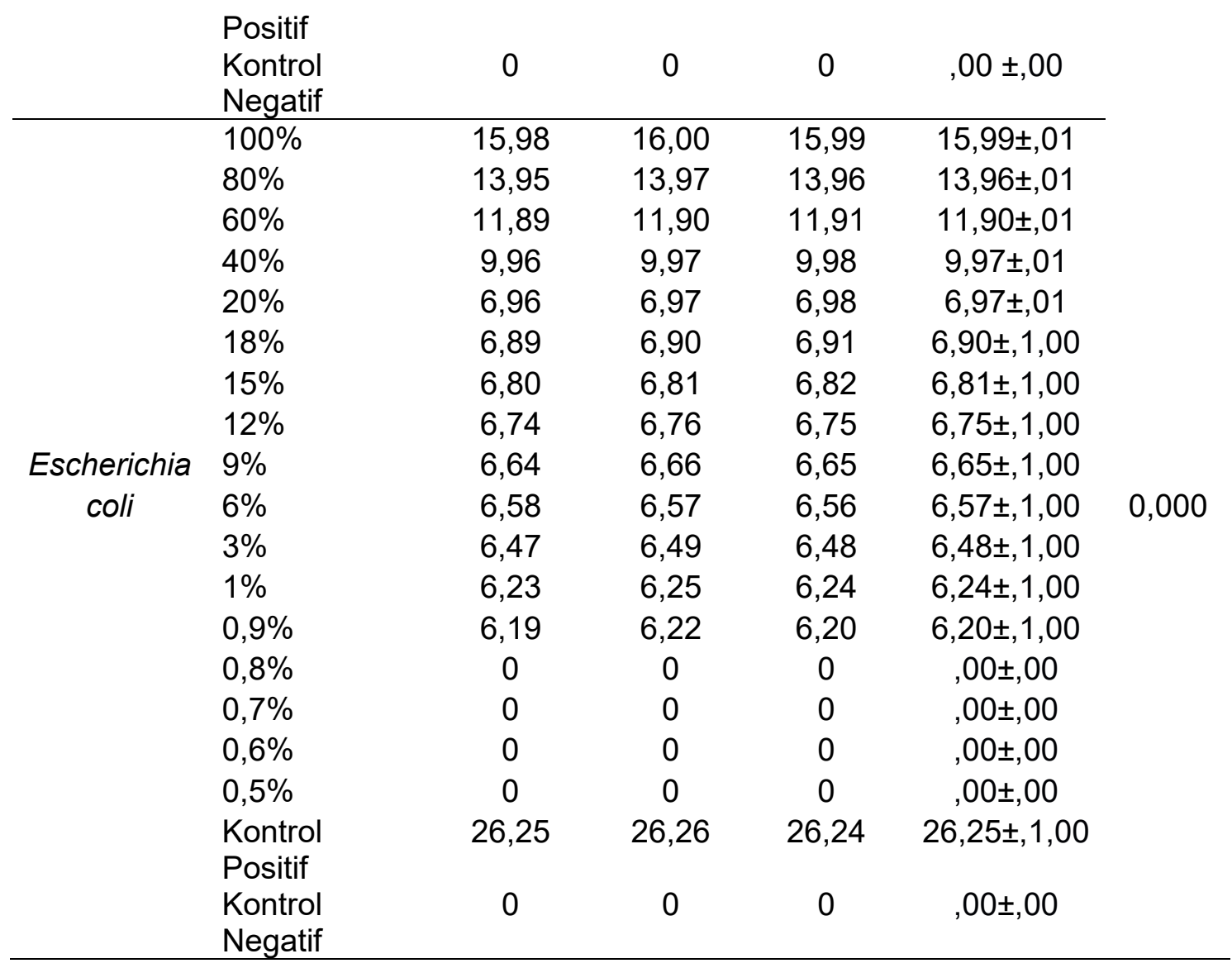


Hasil analisa data menggunakan uji normalitas dengan menggunakan Shapiro wilk menunjukkan nilai signifikan lebih besar dari $(P>0.05)$, yang artinya setiap konsentrasi memiliki daya hambat yang terdistribusi normal.

Pada uji homogenitas, data daya hambat dan konsentrasi memiliki nilai signifikan $(P>0,05)$ maka dapat disimpulkan mempunyai varian yang sama. Data daya hambat pada varisan perbandingan terdistribusi normal dan memiliki hasil yang homogen, maka dilanjutkan analisis dengan menggunakan ANOVA dengan menunjukkan nilai signifikan $0,000<0,05$, yang artinya terdapat perbedaan bermakna antara konsentrasi dari ekstrak bawang dayak (Eleutherine polmifolia (L.) Merr).

Setelah uji ANOVA dilanjutkan dengan uji LSD (Least Significant Differences). Hasil uji LSD menunjukan bahwa dari konsentrasi $100 \%$ sampai $1 \%$ pada bakteri Salmonella typhi aktivitasnya sebanding dengan kontrol positif dengan nilai signifikan $\mathrm{P}<0,05$ yang artinya dari konsentrasi satu dengan yang lain memiliki perbedaan, sedangkan pada konsentrasi $0,9 \%$ sampai $0,5 \%$ dan kontrol negatif memiliki nilai signifikan $\mathrm{P}>0,05$ yang artinya tidak sebanding dengan kontrol positif dan tidak memiliki perbedaan. Pada bakteri Escherichia coli hasil uji LSD menunjukkan bahwa konsentrasi $100 \%$ sampai $0,9 \%$ aktivitasnya sebanding dengan kontrol positif dengan nilai signifikan $\mathrm{P}<0,05$ yang artinya dari konsentrasi satu dengan yang lain memiliki perbedaan, sedangkan konsentrasi $0,8 \%$ sampai $0,5 \%$ dan kontrol negatif memiliki nilai signifikan $P>0,05$ yang artinya tidak sebanding dengan kontrol positif dan tidak memiliki perbedaan. Hasil yang didapat yaitu diameter zona hambat lebih kecil dari diameter kontrol positif. Hasil uji LSD (Least Significant Differences) dapat dilihat pada lampiran 6. Dari hasil uji LSD (Least Significant Differences) aktivitas ekstrak bawang dayak (Eleutherine polmifolia (L.) Merr) pada konsentrasi $100 \%$ berbeda bermakna dengan konsentrasi $1 \%$ dan $0,9 \%$

Ekstrak bawang dayak (Eleutherine polmifolia (L.) Merr) pada konsentrasi $100 \%$ memiliki aktivitas antibakteri kategori sangat kuat, sedangkan pada konsentrasi $80 \%$ sampai $0,9 \%$ memiliki aktivitas antibakteri kategori kuat pada bakteri Salmonella typhi dan Escherichia coli.

\section{Kesimpulan}

Kesimpulan yang diperoleh dari penilitian ini adalah :

1. Ekstrak bawang dayak (Eleutherine polmifolia (L.) Merr) dapat menghambat pertumbuhan bakteri Salmonella typhi dan Escherichia coli.

2. Konsentrasi hambat minimum (KHM) ekstrak bawang dayak (Eleutherine polmifolia (L.) Merr) diperoleh pada konsentrasi $1 \%$ pada bakteri Salmonella tphi dengan diameter zona hambat sebesar $6,22 \mathrm{~mm}$ dan konsentrasi $0,9 \%$ dengan diamater zona hambat sebesar $6,20 \mathrm{~mm}$ pada bakteri Escherichia coli dengan aktivitas antibakteri kategori kuat. 


\section{DAFTAR PUSTAKA}

1. Departemen Kesehatan RI. 2013. Sistematika pedoman pengendalian penyakit demam tifoid. Jakarta: Dirktoral Jendral Pengendalian Penyakit \& Penyehatan Lingkungan.

2. Djauhariyah, E., dan Hernani. 2004. Gulma Khasiat Obat. Jakarta: Seri Agrisehat.

3. Febrinda, A.E. 2013. Potensi Antioksidan dan Antidiabetik Ekstrak Ait dan Etanol Umbi Bawang Dayak (Eleutherine palmifolia (L.) Merr.) Secara In Vitro dan In Vivo [Diserasi]. Sekolah Pascasarjana IPB, Bogor.

4. Hanani, E. 2015. Analisis Fitokimia. Jakarta: EGC. Hal 9$15,79-149,227-241$

5. Kementerian Kesehatan RI. 2017. Profil Kesehatan Indonesia. Kementrian Kesehatan Republik Indonesia, Jakarta.

6. Misna dan Diana, K. 2016. Aktivitas antibakteri ekstrak bawang merah (Allium cepa L.) terhadap bakteri Staphylococcus aureus. GALENIKA Journal of Pharmacy. 2(2):131-144

7. Novaryatiin, S., Pratiwi, A.M., dan Ardhany, S.D. 2018. Uji Daya Hambat Ekstrak Etanol Bawang Dayak (Eleutherine palmifolia (L.) Merr.) terhadap Bakteri Staphylococcus epidrmidis. Jurnal Anterior, 18 (1):92-97

8. Puspadewi, R., Adirestuti, P., dan Menawati, R. 2013. Khasiat umbu

Bawang

dayak
(Eleutherine palmifolia (L.) Merr.) sebagai herbal antimikroba kulit Kartika: Jurnal IImiah Farmasi. 1 (1): 31-37.

9. Safitri, R. dan Sinta, S.N. 2010. Medium analisis mikroorganisme (isolasi dan kultur). Jakarta: Trans Info Media.

10. Sandika, J. dan Suswandi, F.J. 2017. Sensitivitas Salmonella typhi Penyebab Demam Tifoid terhadap beberapa Antibiotik. Majority Jurnal Clinical Gastroenterology and Hepatology

11. Scallan, E., Hoekstra R.M., Angulo F.J., Tauxe R.V., Widdowso M.A., Roy S.L. 2012. Patogens causing US foodborne illnesses, Hospitalizations, and Daths 2000-2008. United States.

12. Warsiti, W., Wardani, S.D., Ramadhan, A.A. dan Yuliani, R., 2018. Uji Aktivitas Antibakteri Ekstrak Etanol Bawang Dayak (Eleutherine palmifolia (L.) Merr) Terhadap Bakteri Staphylococcus aureus. Pharmacon: Jurnal Farmasi Indonesia, 15 (2), pp.7582.

13. WHO. $2018 . \quad W e e k l y$ Epedemiological Record. Genewa : WHO. 